\title{
An Analysis of Pattern and Growth of Fertilizer Consumption in Karnataka State, India
}

\author{
Seddy Bhagyamma* and A.R.S. Bhat \\ Department of Agricultural Statistics, College of Agriculture, University of Agricultural \\ Sciences, Dharwad-580 00, Karnataka, India \\ *Corresponding author
}

\section{A B S T R A C T}

\begin{tabular}{|l|}
\hline K e y w o r d s \\
$\begin{array}{l}\text { Fertilizer consumption } \\
\text { pattern, Compound } \\
\text { annual growth rate, } \\
\text { Recommended dose of } \\
\text { fertilizer. }\end{array}$ \\
\hline Article Info \\
\hline $\begin{array}{l}\text { Accepted: } \\
\text { 07 October } 2017 \\
\text { Available Online: } \\
\text { 10 December } 2017\end{array}$ \\
\hline
\end{tabular}

\section{Introduction}

The use of fertilizer depends largely on the availability of irrigation facilities and availability of working capital with the farmers for acquiring the purchased inputs. The farmers may also have different attitudes to different crops grown on the farm regarding to application of fertilizer. This may be influenced by the relative profitability of the crops, degree of yield and price risks involved and the personal likings and consumption needs of the farm family (Kaushik and Paharia, 2014).

India made impressive gains in the field of agricultural production and harvested a record in food grains production of 230 million tonnes during 2007-08. Introduction of HYV's and hybrid varieties brought optimism about fertilizer response superiority of modern varieties. The total nutrient consumption $\left(\mathrm{N}+\mathrm{P}_{2} \mathrm{O}_{5}+\mathrm{K}_{2} \mathrm{O}\right)$ touched level of 264 lakh million tonnes during 2009-10, the highest so far.

Since the rain fed areas, which constitute $70 \%$ of the cultivated areas, consume only $20 \%$ of the total fertilizers, the government has been taking steps in recent years to increase the consumption of fertilizers in these areas. Even though India is the third largest fertilizer user, average rate of nutrient application is only 85 $\mathrm{kg} \mathrm{ha}^{-1}$ (Mala, 2013). 
The present study was undertaken in the Davangere and Dharwad districts of Karnataka, where the consumption of fertilizers per hectare of cropped area is very high, to examine the pattern and efficiency of fertilizer use in the major crops of the district.

\section{Materials and Methods}

\section{Tabular presentation/analysis}

This technique was exclusively used for the presentation of fertilizer use in different cropping situations.

Differences in recommended dose of fertilizer used in different cropping situation both in irrigated and rain fed condition.

The number of farmers using recommended, less than the recommended and more than the recommended dose of $\mathrm{N}: \mathrm{P}_{2} \mathrm{O}_{5}: \mathrm{K}_{2} \mathrm{O}$ was estimated in irrigated and rain fed condition. The quantities of $\mathrm{N}: \mathrm{P}_{2} \mathrm{O}_{5}: \quad \mathrm{K}_{2} \mathrm{O}$ were calculated by aggregate percentage.

\section{Growth rate analysis}

In order to analyze the growth of fertilizer consumption over a period of years compound growth rates were computed using the following model.

$Y_{t}=a b^{t} e^{u}$

Where,

$\mathrm{Y}_{\mathrm{t}}=$ dependent variable

$\mathrm{a}=$ intercept term

$\mathrm{b}=(1+\mathrm{r})$ and ' $\mathrm{r}$ ' is the compound growth rate

$\mathrm{t}=$ time trend

$\mathrm{u}=$ error term
The above model in the Logarithmic form is expressed as, $\log Y=\log a+t \log b+\log u$

Log a and Log b values were obtained using the ordinary least squares procedures and the $\mathrm{R}^{2}$ was computed for testing the goodness of fit. Antilog of $\log (b-1) * 100$ give the per cent growth rate. Significance of the growth rate was tested using ' $t$ ' test.

\section{Results and Discussion}

The findings of the study indicated that NPK usage pattern in Dharwad district had negative growth rate $(-5.77 \%)$ over the years (2004-2015). Amongst all the three major nutrients, usage of phosphatic fertilizer showed highest negative growth $(-7.70 \%)$ followed by nitrogen $(-3.95 \%)$ and potassic fertilizer (-3.39\%) (Fig. 1).

The results of compound annual growth rate analysis of NPK consumption in Dharwad have been presented in Table 1. It was found that consumption of NPK decreasing over the period as indicated by negative growth rates.

This was mainly due to variation in the climatic condition in the district, which might have resulted in drastic reduction in consumption of fertilizer. Cost of fertilizer also plays important role in decreasing growth rate of NPK consumption.

NPK consumption of Davangere district was presented in the Table 2. It was revealed that consumption of nitrogenous fertilizer showed the highest growth rate $(5.38 \%)$ and it was found to be significant at 1 per cent level of significance with $\mathrm{R}^{2}$ value 0.45 per cent. This might be due to increase area under irrigation in Davangere district, apart from irrigation, technological changes and spread of HYV's had also made significant impact on use of fertilizers. Similar findings were reported by Patil and Pandey (1981) (Fig. 2). 
Table.1 NPK consumption in Dharwad district (2004-2015)

\begin{tabular}{|c|c|c|c|c|}
\hline \multicolumn{5}{|c|}{ Million Tonnes } \\
\hline Year & $\mathbf{N}$ & $\mathbf{P}$ & $\mathbf{K}$ & Total \\
\hline $2004-5$ & 7216.4 & 28474 & 11471 & 47161.4 \\
\hline $2005-6$ & 6113.8 & 20705.5 & 10969 & 37788.3 \\
\hline $2006-7$ & 5010.6 & 16334 & 10409 & 31753.6 \\
\hline $2007-8$ & 4899.6 & 16899.5 & 10822 & 32621.1 \\
\hline $2008-9$ & 4587 & 17502 & 9251 & 31340 \\
\hline $2009-10$ & 4548.8 & 22511 & 11422 & 38481.8 \\
\hline $2010-11$ & 4538 & 17201 & 9690 & 31429 \\
\hline $2011-12$ & 4528 & 12470 & 7960 & 24958 \\
\hline $2012-13$ & 4423 & 11683.5 & 8261 & 24367.5 \\
\hline $2013-14$ & 4318.6 & 10899 & 8563 & 23780.6 \\
\hline $2014-15$ & 4370.8 & 11291.25 & 8412 & 24074.05 \\
\hline CAGR & -3.95618 & -7.707 & -3.39786 & -5.77361 \\
\hline$R^{2}$ & $0.687107 * *$ & $0.736572^{* *}$ & $0.692906 * *$ & $0.771123^{* *}$ \\
\hline
\end{tabular}

Table.2 NPK consumption in Davangere district (1997-2015)

\begin{tabular}{|c|c|c|c|c|}
\hline Year & $\mathbf{N}$ & $\mathbf{P}$ & $\mathbf{K}$ & Total \\
\hline $1997-98$ & 24630 & 13822 & 8604 & 47056 \\
\hline $1998-99$ & 30320 & 16685 & 6850 & 53855 \\
\hline $1999-00$ & 32330 & 22505 & 8860 & 63695 \\
\hline $2000-01$ & 44453 & 25941 & 9296 & 79690 \\
\hline $2001-02$ & 20100 & 10700 & 4150 & 34950 \\
\hline $2002-03$ & 18430 & 9000 & 3910 & 31340 \\
\hline $2003-04$ & 38795 & 27005 & 10631 & 76431 \\
\hline $2004-05$ & 53549 & 29299 & 12173 & 95021 \\
\hline $2005-06$ & 62571 & 34693 & 14098 & 111362 \\
\hline $2006-07$ & 43463 & 26375 & 9857 & 79695 \\
\hline $2007-08$ & 66115 & 36068 & 14778 & 116961 \\
\hline $2008-09$ & 68428 & 37331 & 15294 & 121053 \\
\hline $2009-10$ & 46211.6 & 26268.0 & 10465.2 & 82944.78 \\
\hline $2010-11$ & 70673.2 & 20122.39 & 437.5 & 91233.09 \\
\hline $2011-12$ & 44290.6 & 23986.7 & 9243.1 & 77520.49 \\
\hline $2012-13$ & 45695.0 & 24712.8 & 9288.8 & 79696.53 \\
\hline $2013-14$ & 67015 & 22915 & 10046 & 99976 \\
\hline $2014-15$ & 54777.1 & 23601.0 & 7896.1 & 86274.18 \\
\hline CAGR & 5.382 & 3.076 & -0.666 & 4.239 \\
\hline$R^{2}$ & $0.455433 * *$ & 0.172014 & 0.001965 & $0.334076^{* *}$ \\
\hline
\end{tabular}


Table.3 Pattern of fertilizer use under major crops of Dharwad district

\begin{tabular}{|c|c|c|c|c|c|c|c|c|c|c|c|c|c|}
\hline \multirow{3}{*}{ Variable } & \multirow{3}{*}{ Category } & \multicolumn{4}{|c|}{ Maize } & \multicolumn{4}{|c|}{ Bt Cotton } & \multicolumn{4}{|c|}{ Soybean } \\
\hline & & \multicolumn{2}{|c|}{ Irrigated } & \multicolumn{2}{|c|}{ Rain fed } & \multicolumn{2}{|c|}{ Irrigated } & \multicolumn{2}{|c|}{ Rain fed } & \multicolumn{2}{|c|}{ Irrigated } & \multicolumn{2}{|c|}{ Rain fed } \\
\hline & & $\mathbf{F}$ & $\%$ & $\mathbf{F}$ & $\%$ & $\mathbf{F}$ & $\%$ & $\mathbf{F}$ & $\%$ & $\mathbf{F}$ & $\%$ & $\mathbf{F}$ & $\%$ \\
\hline \multirow{4}{*}{$\mathrm{N}: \mathrm{P}_{2} \mathrm{O}_{5}: \mathrm{K}_{2} \mathrm{O}$} & $<$ Recommended & 8 & 26.67 & 25 & 47.92 & 6 & 35.19 & 15 & 56.41 & 3 & 15.00 & 6 & 19.75 \\
\hline & Recommended & 5 & 17.78 & 3 & 4.86 & 1 & 3.70 & 4 & 15.38 & 4 & 18.33 & 8 & 30.86 \\
\hline & > Recommended & 17 & 55.56 & 25 & 47.22 & 11 & 61.11 & 7 & 28.21 & 14 & 66.67 & 13 & 49.38 \\
\hline & Total & \multicolumn{2}{|c|}{30} & \multicolumn{2}{|c|}{53} & & 18 & \multicolumn{2}{|c|}{26} & & 21 & \multicolumn{2}{|c|}{27} \\
\hline
\end{tabular}

** Significant at $1 \%$

Table.4 Pattern of fertilizer use under major crops of Davangere district

\begin{tabular}{|c|c|c|c|c|c|c|c|c|c|}
\hline \multirow{3}{*}{ Variable } & \multirow{3}{*}{ Category } & \multicolumn{4}{|c|}{ Maize } & \multirow{2}{*}{\multicolumn{2}{|c|}{\begin{tabular}{|c|} 
Paddy \\
Irrigated
\end{tabular}}} & \multirow{2}{*}{\multicolumn{2}{|c|}{$\begin{array}{c}\text { Jowar } \\
\text { Rainfed } \\
\end{array}$}} \\
\hline & & \multicolumn{2}{|c|}{ Irrigated } & \multicolumn{2}{|c|}{ Rainfed } & & & & \\
\hline & & $\mathbf{F}$ & $\%$ & $\mathbf{F}$ & $\%$ & $\mathbf{F}$ & $\%$ & $\mathbf{F}$ & $\%$ \\
\hline \multirow{5}{*}{$\mathrm{N}: \mathrm{P}_{2} \mathrm{O}_{5}: \mathrm{K}_{2} \mathrm{O}$} & $<$ Recommended & 11 & 34.41 & 17 & 47.62 & 20 & 41.84 & 36 & 72.79 \\
\hline & Recommended & 6 & 20.43 & 6 & 17.14 & 7 & 14.89 & 8 & 17.01 \\
\hline & > Recommended & 14 & 45.16 & 12 & 35.24 & 21 & 43.26 & 5 & 10.20 \\
\hline & Total & & 31 & & 35 & \multicolumn{2}{|c|}{48} & \multicolumn{2}{|c|}{49} \\
\hline & $\begin{array}{c}\text { Chi square } \\
\text { value }\end{array}$ & \multicolumn{4}{|c|}{$31.00 * * *$} & & - & & 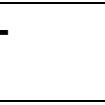 \\
\hline
\end{tabular}

** Significant at $1 \%$

Fig.1 Pattern of fertilizer use in Dharwad district

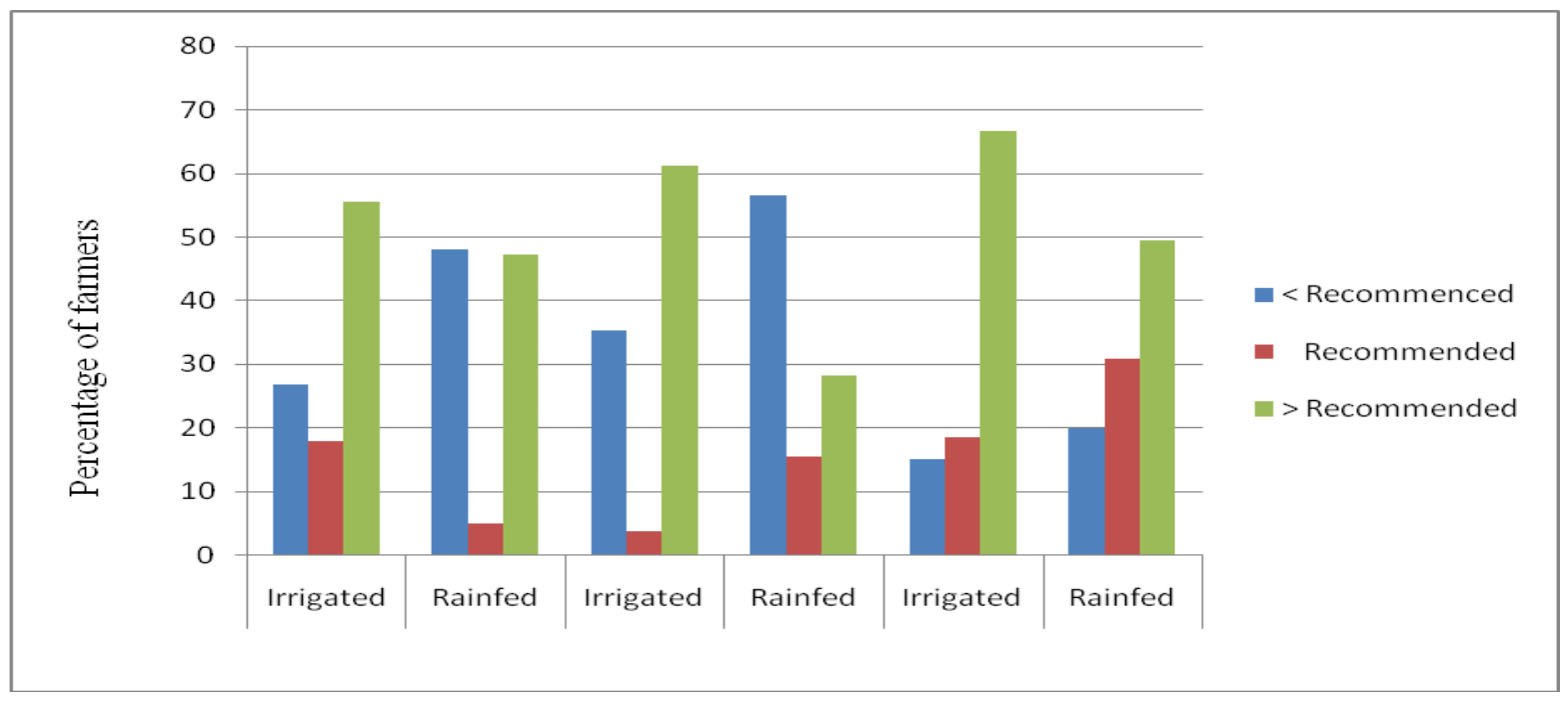


Fig.2 Pattern of fertilizer use in Davangere district

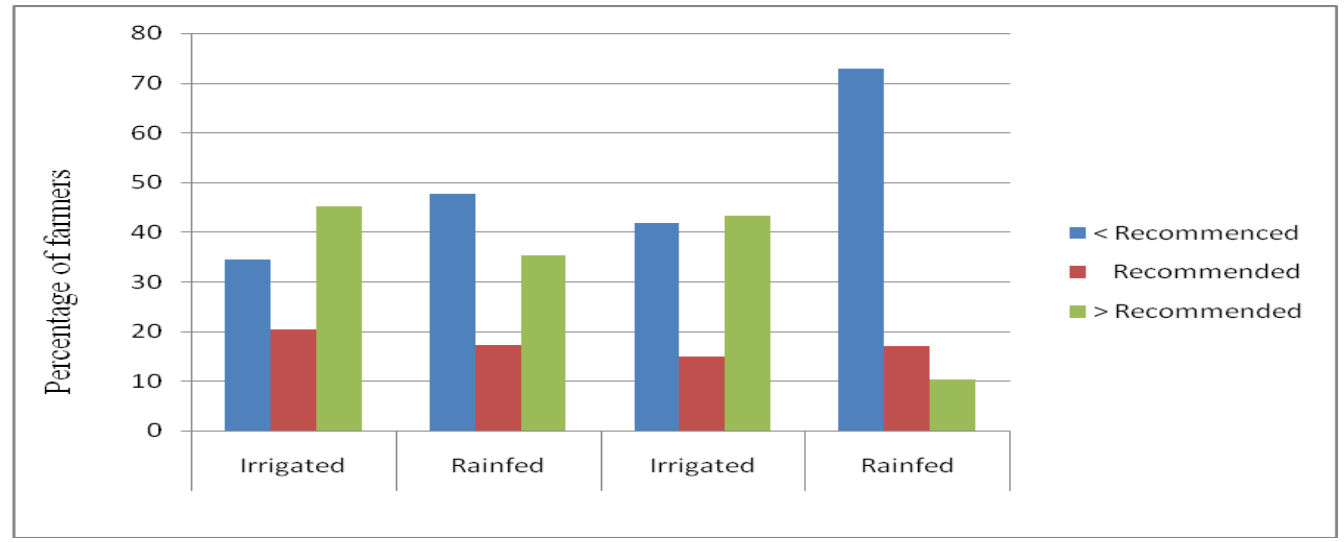

In case of phosphatic fertilizers it was observed that the $\mathrm{P}$ consumption increased over the period with growth rate of 3.07 per cent per annum in Davangere district. Irrigation was the most dominating factor for increasing fertilizer consumption. Apart from this, improved farm technology and management practices were expected to increase future consumption of $\mathrm{P}$ fertilizers. The results obtained for consumption of phosphatic fertilizers were in line with Patil and Pandey (1981), wherein they had examined the influence of economic factors on application of phosphatic fertilizer at micro level. The study revealed that irrigation was the most dominating factor for increasing fertilizer consumption.

From the Table 2, it was observed that potassium fertilizer showed decreasing trend with high negative growth rate $(-0.66 \%)$, this may be due to in recent years farmers were aware of package of practices and balanced nutrition and they were following recommended dosage of NPK fertilizers. In that recommended $\mathrm{K}$ dose was very less, because of the fact that potash content in black cotton soil is very high.

\section{Pattern of fertilizer use}

From the Table 3 it is concluded that farmers were applying more than the RDF in irrigated condition as compared to rain fed condition. It also clear that more number of farmers were using the more than the RDF than the RDF and less than the RDF in all the three crops. This might be due to spread of high yielding varieties (HYV's), use of fertilizer intensive crops and also because the cropping intensity in irrigated areas was significantly high compared to rain fed condition. The chi square value indicates that there is no association between pattern of fertilizer use and conditions of the crop grown in case of maize and $\mathrm{Bt}$ cotton. Whereas in case of soybean the chi square value indicates that there is a significant association between pattern of fertilizer use and condition of the crop grown. The percentage of farmers using the more than the RDF was more in irrigated condition as compared to rainfed situation.

From the Table 4 that the intensity of use of more than the RDF was more in irrigated condition than the rain fed condition in case of maize crop. This might be due to the use of HYV's and availability of irrigation facility. Similar also same findings were also found in the paddy crop. In the case of sorghum crop more number of farmers were using less than or more than the RDF. This might be due to the reason that sorghum crop was grown mainly in rain fed condition and in rain fed condition, the application of fertilizer will be less because of scarcity of water facility. The 
chi square value is 31.00 which is significant at 1 per cent level of significance in case of maize crop. It indicates that percentage of farmers using the more than the RDF was more in irrigated condition as compared to rainfed situation.

This study focused on pattern of fertilizer consumption of selected district of Karnataka state. NPK usage pattern in Dharwad district showing negative growth rate over the period (2004-05 to 2014-15).

Amongst all the three major nutrients usage of phosphorous fertilizer showing highest negative growth rate $(-7.70 \%)$ followed by nitrogenous $(-3.95 \%)$ and potassium fertilizer $(-3.39 \%)$. Overall consumption of NPK was also showing negative growth rate $(-5.77 \%)$. It shows that consumption is decreasing over the period with negative growth rate.

In Davangere district, it is observed that usage of nitrogenous fertilizer (5.38\%) and phosphatic (3.07\%) fertilizer are showing the positive growth rates. But, in case of pottasic fertilizer, it was reverse trend i.e., consumption is decreasing over the period with negative growth rates $(-0.66 \%)$.

The findings of this study revealed that levels of NPK usage under irrigated conditions in case of maize, BT cotton and soybean were relatively high as compared to rain fed conditions.

Majority of the farmers using more than the RDF in case of irrigated condition as compared to rainfed condition in case of maize, Bt cotton, and soybean. It is observed that in rainfed condition farmers using the less than the RDF.

\section{References}

Anjurani., 2014, Consumption of chemical fertilizers in Haryana: an empirical study. International Journal of Business Economics \& Management Research. 4(7): 105-112

Jayanthi, G., Sherley Thomas, D. R., Benny J. Godwin., 2013. An analysis of pattern and growth of fertilizer consumption in india $(1980-81$ to 2009 - 10). The South Asian Academic Research Journals.3(1): 197-212.

Jha, D. and Sarin, R., 1980, Fertilizer consumption and growth in semi-arid tropical India - A district level analysis. Economic programs. Progress Report No. 10, ICRISAT, Andra Pradesh.

Kaushik, V.K. and Paharia, N.C., 2014, Pattern of fertilizer use on major crops grown in Hissar district of Haryana. Int.J.Curr.Microbiol.App.Sci, 3(7): 665672.

Krishnmacharyulu, T.V. and Muralidhar, V., 1981, Interstate variations in trend of fertilizer use - A time series analysis. Fertilizer Marketing News, 12(12): 3-6.

Mala P., 2013, IJSSIS. Fertilizer scenario in India, vol. 2: 62-72.

Patil, A. S. and Pandey R. K., 1981, Demand for nirogenous fertilizers in Indian agriculture. Fertilizer News, 26(12): 1619.

\section{How to cite this article:}

Seddy Bhagyamma and Bhat, A.R.S. 2017. An Analysis of Pattern and Growth of Fertilizer Consumption in Karnataka State. Int.J.Curr.Microbiol.App.Sci. 6(12): 568-573. doi: https://doi.org/10.20546/ijcmas.2017.612.069 